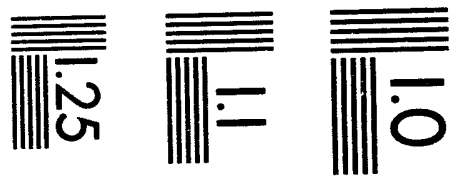

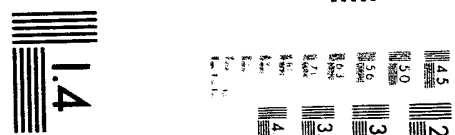

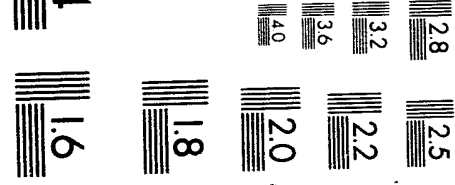



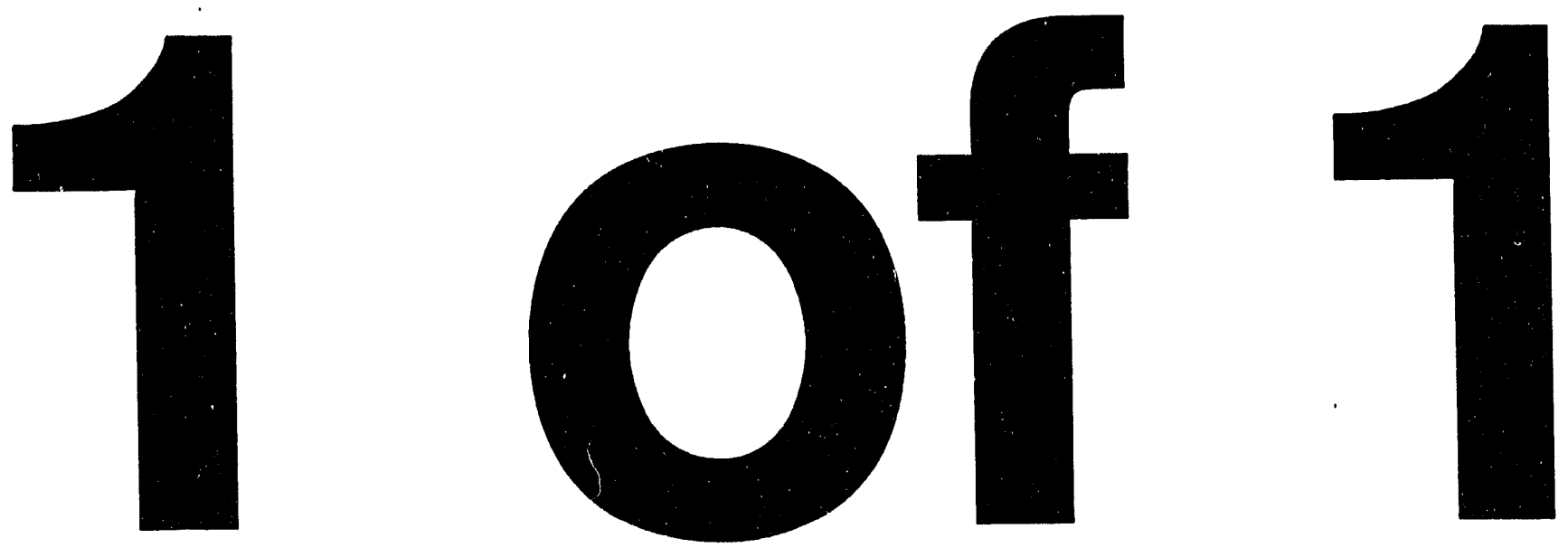


\title{
INCORPORATING LONG-TERM CLIMATE CHANGE IN PERFORMANCE ASSESSMENT FOR THE WASTE ISOLATION PILOT PLANT
}

\author{
Peter N. Swift \\ WIPP Performance Assessment Department 6342, MS-1328 \\ Sandia National Laboratories, Albuquerque, NM 87185 \\ Bruce L. Baker \\ Technadyne Engineering Consultants, Inc., Albuquerque, NM \\ Kathy Economy \\ Ecodynamics Research Associates, Albuquerque, NM \\ James W. Garner \\ Applied Physics, Inc., Albuquerque, NM \\ Jon C. Helton \\ Arizona State University, Tempe, AZ \\ David K. Rudeen \\ New Mexico Engineering Research Institute, Albuquerque, NM
}

\begin{abstract}
The United States Department of Energy (DOE) is developing the Waste Isolation Pilot Plant (WIPP) in southeastern New Mexico for the disposal of transuranic wastes generated by defense programs. Applicable regulations ( 40 CFR 191) require the DOE to evaluate disposal-system performance for $10,000 \mathrm{yr}$. Climatic changes may affect performance by altering grcundwater flow.
\end{abstract}

Paleoclimatic data from southeastern New Mexico and the surrounding area indicate that the wettest and coolest Quaternary climate at the site can be represented by that at the last glacial maximum, when mean annual precipitation was approximately twice that of the present. The hottest and driest climates have been similar to that of the present. The regularity of global glacial cycles during the late Pleistocene confirms that the climate of the last glacial maximum is suitable for use as a cooler and wetter bound for variability during the next 10,000 yr. Climate variability is incorporated into groundwater-flow modeling for WIPP PA by causing hydraulic head in a portion of the model-domain boundary to rise to the ground surface with hypothetical increases in precipitation during the next 10,000 yr. Variability in modeled disposal-system performance introduced by allowing head values to vary over this range is insignificant compared to variability resulting from other causes, including incomplete understanding of transport processes. Preliminary performance assessments suggest that climate variability will not affect regulatory compliance.

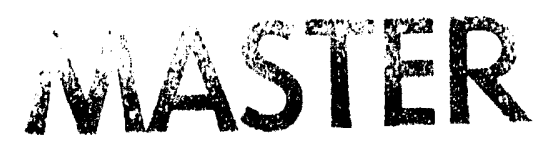




\section{ACKNOWLEDGMENTS}

This work was performed at Sandia National Laboratories, Albuquerque, NM, and was supported by the United States Department of Energy under Contract DE-AC04-76DP00789. The authors are members of the WIPP Performance Assessment Department (6342) at Sandia National Laboratories, and gratefully acknowledge contributions of approximately 40 colleagues in the department who have also worked on WIPP performance assessment under the direction of D. R. Anderson. T.F. Corbet and C.L. Axness provided critical reviews of the manuscript. Illustrations and editorial support were provided by D. Marchand, H. Olmstead, and F. Puffer of Tech Reps, Inc. This report will also be published in the Proceedings of the Thirty-Second Hanford Symposium on Health and the Environment; Regional Impacts of Global Climate Change: Assessing Change and Response at the Scales that Matter, Richland, WA, October 19-21, 1993. 


\section{INTRODUCTION}

The Waste Isolation Pilot Plant (WIPP) is planned as a research and development facility to demonstrate the safe disposal of transuranic wastes generated by the United States Department of Energy (DOE). It is located in semiarid rangeland in southeastern New Mexico $42 \mathrm{~km}$ east-southeast of the city of Carlsbad (Figure 1), at a surface elevation of $1040 \mathrm{~m}$ above mean sea level. Bedded halite of the Late Permian Salado Formation (approximately 255 million yr old) has been selected as the host strata because of its extremely low permeability, long-term geologic stability, and creep properties that facilitate sealing. Excavation of the waste-emplacement panels $655 \mathrm{~m}$ below the ground surface is partially complete, and additional panels will be excavated in the future as needed.

No transuranic waste is presently at the WIPP, and before disposing of waste in the facility the DOE must evaluate compliance with applicable long-term regulations of the United States Environmental Protection Agency (EPA). The regulation of interest here is Subpart B of 40 CFR 191 (Environmental Standards for the Management and Disposal of Spent Nuclear Fuel, High-Level and Transuranic Radioactive Wastes, Final Rule [US EPA, 1985]), which requires evaluation of the consequences of future inadvertent intrusion into the repository. As discussed below, climate change will affect performance only if the repository is breached. Compliance with long-term regulations for which human intrusion does not apply, including those implementing the Resource Conservation and Recovery Act (RCRA), will not be affected.

Sandia National Laboratories is performing iterative preliminary performance assessments (PAs) to provide guidance to the WIPP Project while preparing for final evaluations of compliance with applicable long-term regulations. Preliminary PAs for the WIPP have been performed in 1990 (Bertram-Howery et al., 1990; Rechard et al., 1990; Helton et al., 1991), 1991 (WIPP PA Division, 1991 a,b,c; Helton et al., 1992), and 1992 (WIPP PA Department, 1992 a,b; Sandia WIPP Project, 1992; WIPP PA Department 1993 a,b). As stipulated by Congress (Public Law 102-579, 1992), biennial preliminary PAs will continue to be performed for the WIPP until the DOE is prepared to submit a final PA to the EPA (currently scheduled for 1998).

The Containment Requirements of 40 CFR 191 set probabilistic limits on the 10,000-yr cumulative releases of radionuclides at the "accessible environment" boundary, which is the ground surface and, for the WIPP, a vertical plane in the subsurface $2.4 \mathrm{~km}$ at its closest point from the waste (WIPP PA Department, 1992a, 1993a). The regulation requires estimating the probability of all releases, and allows larger releases at lower probabilities. "Inadvertent human intrusion" (e.g., by drilling during future exploration for natural resources) must be considered as a possible event.

Preliminary PAs to date indicate that, without human intrusion, the repository will comply with 40 CFR 191 B without difficulty (WIPP PA Department, 1992a, 1993a). Significant quantities of radionuclides from the WIPP will be transported only as solutes in a liquid phase (brine), and all modeling to date indicates that brine will not migrate more than a few tens of meters from the waste in 10,000 yr if the waste-disposal panels are not breached by intrusion (WIPP PA Department, 1993a,b). However, if human intrusion occurs, radionuclides may reach the accessible environment by two paths. First, some material will be brought to the ground surface immediately during drilling. This release may be important for iegulatory compliance (WIPP PA Department, 1992a), but will not be affected by climate change and is not discussed further here. Second, additional radionuclides may reach the subsurface boundary of the accessible environment long after the intruding borehole is abandoned, by transport as 


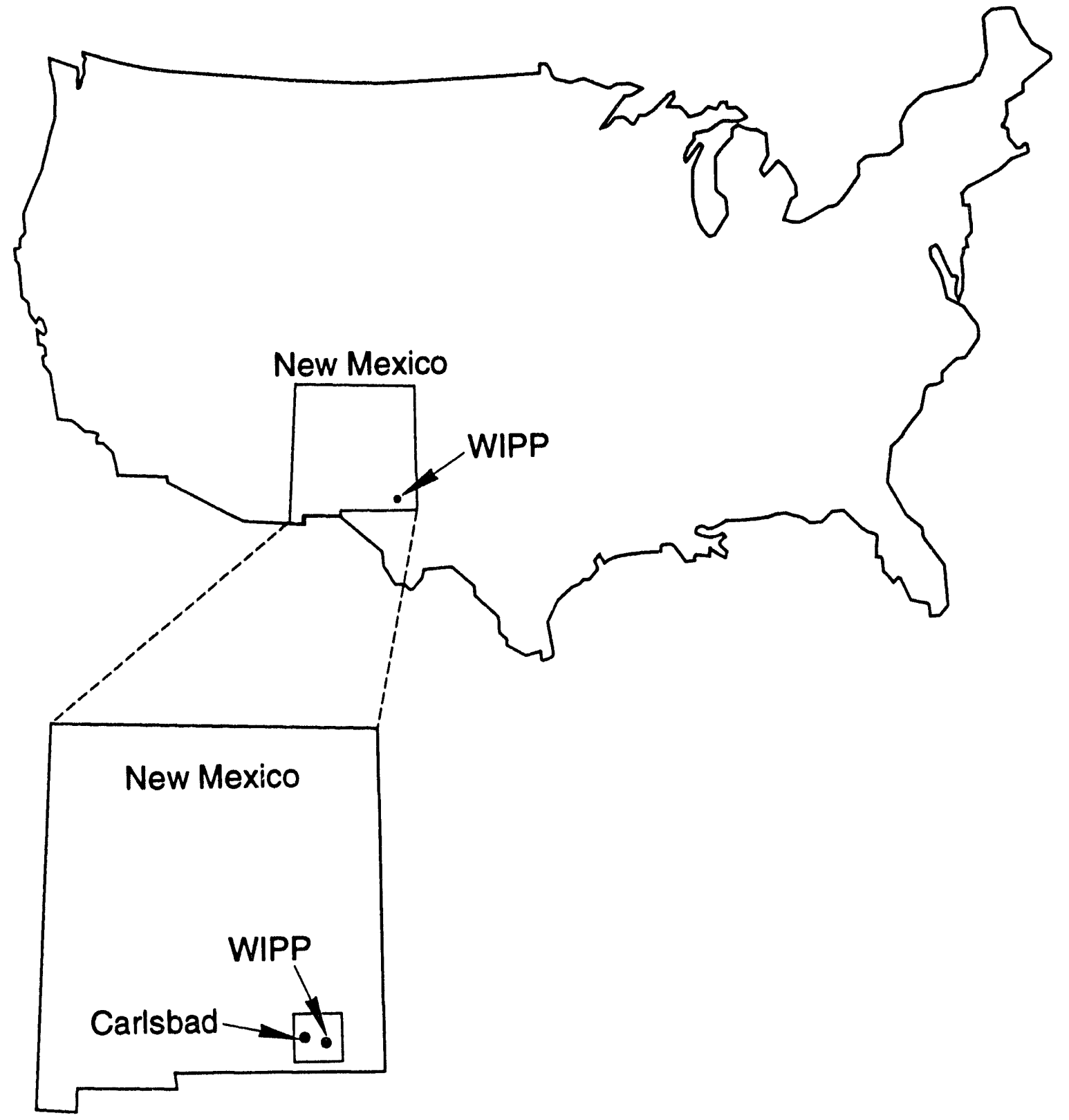

TRI-6342-223-4

Figure 1. Location of the Waste Isolation Pilot Plant. 
solutes in brine that migrates up the borehole and laterally away from the repository in an overlying permeable unit (the Culebra Dolomite Member of the Late Permian Rustler Formation). Long-term changes in climate have the potential to affect disposal-system performance by altering flow and transport in this subsurface pathway.

\section{Long-Term Climate Variability}

\section{Present Climate}

Mean annual precipitation at the WIPP has been estimated to be between 28 and $34 \mathrm{~cm} / \mathrm{yr}$ (Hunter, 1985). Freshwater pan evaporation in the region is estimated to be $280 \mathrm{~cm} / \mathrm{yr}$ (US DOE, 1980). At Carlsbad (100m lower than the WIPP surface elevation), $53 \mathrm{yr}$ (1931-1983) annual means for precipitation and temperature are $32 \mathrm{~cm} / \mathrm{yr}$ and $17.1^{\circ} \mathrm{C}$ (University of New Mexico, 1989). Annual precipitation is dominated by a late summer monsoon, when solar warming of the continent creates an atmospheric pressure gradient that draws moist air inland from the Gulf of Mexico (Cole, 1975). Winters are generally cool and dry.

\section{Paleoclimates and Climatic Variability}

Geologic data from southeastern New Mexico and the surrounding region show repeated alternations of wetter and drier climates throughout the Pleisiocene, corresponding to global cycles of glaciation and deglaciation. Data from plant and animal remains and paleo-lake levels permit quantitative climate reconstructions for the region only for the last glacial cycle, and confirm the interpretation that conditions were coolest and wettest during glacial maxima (Swift, 1993). The hottest and driest conditions since the last glaciation have been similar to those of the present. Modeling of global circulation patterns suggests that these changes resulted from the disruption and southward displacement of the winter jet stream by the ice sheet, causing an increase in the frequency and intensity of winter storms throughout the American Southwest (COHMAP Members, 1988). Mean annual precipitation 22,000 to $18,000 \mathrm{yr}$ ago, when the last North American ice sheet reached its southern limit roughly $1500 \mathrm{~km}$ north of the WIPP, was approximately twice that of the present (Figure 2). Mean annual temperatures may have been as much as $5^{\circ} \mathrm{C}$ colder than at present.

Glacial periodicities have been stable for the last $800,000 \mathrm{yr}$ (Milankovitch, 1941; Hays et al., 1976; Imbrie et al., 1984; Imbrie, 1985). Barring anthropogenic changes in the Earth's climate, relatively simple modeling of climatic response to orbital changes in insolation suggests that the next glacial maximum will occur in approximately $60,000 \mathrm{yr}$ (Imbrie and Imbrie, 1980). The extent to which unprecedented anthropogenic climate changes may alter this conclusion is uncertain, but presently available models of climatic response to an enhanced greenhouse effect (e.g., Mitchell, 1989; Houghton et al., 1990) do not predict changes of a larger magnitude than those of the Pleistocene. Furthermore, published models do not suggest significant increases in precipitation in southeastern New Mexico following global warming (Washington and Meehl, 1984; Wilson and Mitchell, 1987; Schlesinger and Mitchell, 1987; Houghton et al., 1990). Even allowing for anthropogenic change, climate variability at the WIPP can be bounded by Pleistocene extremes (Swift, 1993).

Relatively shorter-term climatic fluctuations have occurred throughout the Pleistocene and Holocene with periodicities on the scale of hundreds to thousands of years (Figure 2). The causes of these nonglacial fluctuations are, in general, unknown, but paleoclimatic data indicate that precipitation may have approached glacial highs at 


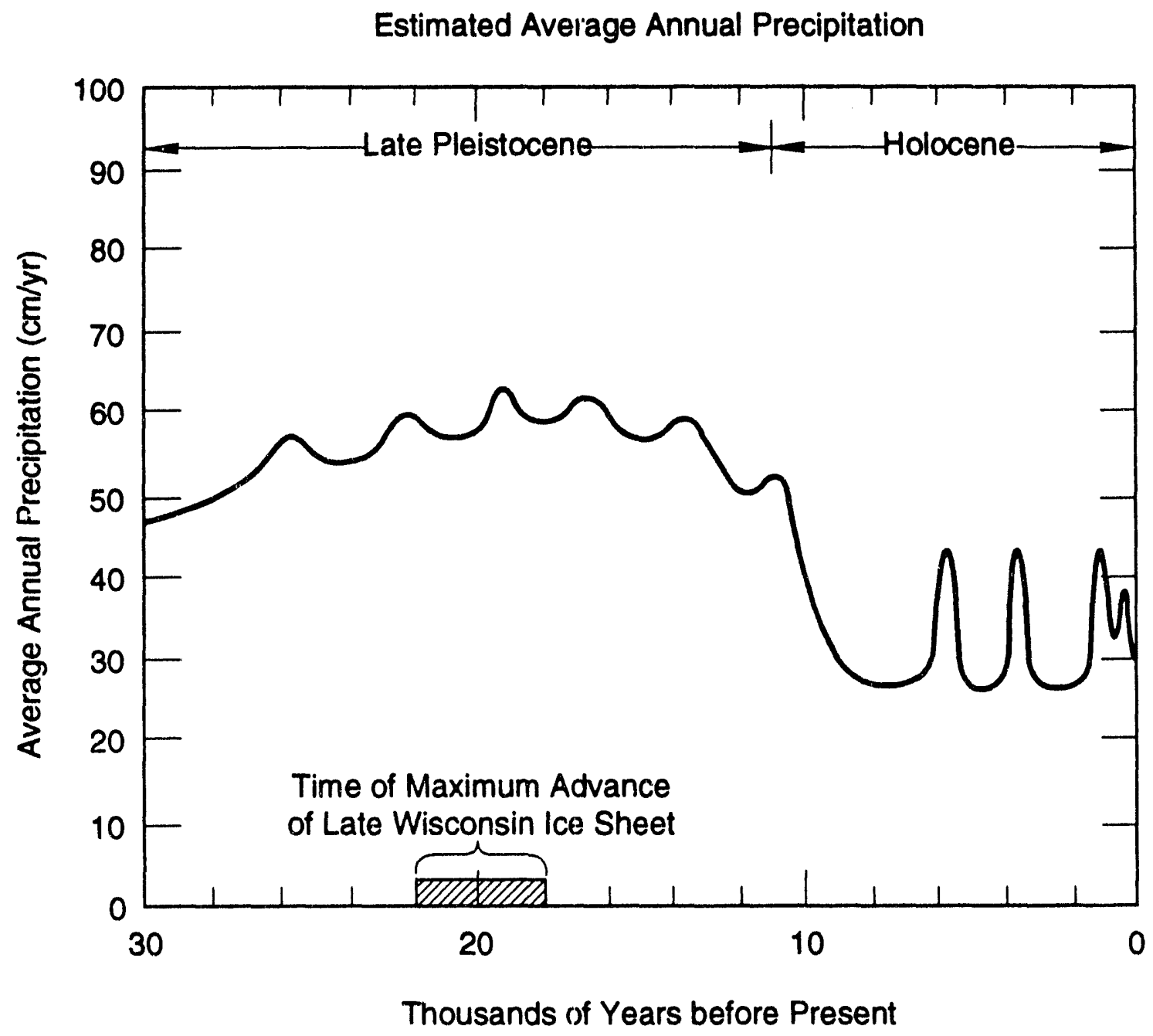

TR1-6342-299-5

Figure 2. Estimated mean annual precipitation at the WIPP during the late Pleistocene and Holocene (Swift, 1993). 
some times during the Holocene (Swift, 1993). Based on the past record, fluctuations of this sort are probable during the next 10,000 yr, and must be included in long-term assessments. The climate-variability model selected for WIPP PA conceptually incorporates uncertainty in both glacial and nonglacial climatic fluctuations by allowing conditions to reach, at a maximum, glacial extremes three times during the next $10,000 \mathrm{yr}$.

\section{Hydrologic Modeling}

WIPP PA models groundwater flow and radionuclide transport in the Culebra Dolomite Member of the Rustler Formation because it is the most transmissive water-saturated unit above the repository (WIPP PA Department 1992b, 1993a). Present groundwater flow is substantially less in other units, and only the Culebra is considered to represent a possible pathway for radionuclide release.

The Culebra is a fractured dolomite approximately $7 \mathrm{~m}$ thick, and is present throughout the region of interest at depths typically of $200 \mathrm{~m}$ or greater. In most locations, it is bounded above and below by low-permeability mudstones and evaporites (Beauheim and Holt, 1990; Brinster, 1991). WIPP PA modeling treats the Culebra as a perfectly confined aquifer, with flow occurring only in two dimensions in the model domain (Figure 3) (WIPP PA Department 1992b, 1993a).

No direct evidence exists for the location of either recharge to or discharge from the Culebra. Potentiometricsurface maps constructed from available well data imply inflow to the model domain from the north and outflow to the south. Mercer (1983) suggested that recharge probably occurs 15 to $30 \mathrm{~km}$ northwest of the WIPP where the Rustler Formation crops out. Lambert (1991) and Lambert and Carter (1987) have speculated on the basis of isotopic evidence that little if any recharge may be occurring now and that present flow reflects long-term draining from recharge during Pleistocene glacial periods. Preliminary modeling indicates that long-term draining is not incompatible with observed hydraulic properties (Davies, 1989; Corbet and Wallace, 1993). Three-dimensional regional flow modeling in progress will permit additional testing of this hypothesis and provide an improved model for the spatial and temporal variability in vertical flux (Corbet and Wallace, 1993).

For the purposes of PA modeling, the location of recharge is unspecified, but is assumed to occur north of the model domain. The amount of present recharge is not specified, except through the assumption that present hydraulic head vaiues within the model domain reflect steady-state conditions. Changes in recharge are not modeled explicitly because the assumed recharge area is outside the model domain, and are instead approximated by varying head values in a "recharge strip" through which most inflow occurs along the northern edges of the model domain (Figure 3). Heads are not varied along other boundaries, reflecting the belief that all recharge occurs north of the model domain. For the 1991 and 1992 preliminary PAs, climatic variability in recharge to the Culebra has been approximated using the following relationship (Swift, 1991; WIPP PA Division, 1991b,c; Helton et al., 1992):

$$
\frac{h_{f}(t)}{h_{p}}=\frac{3 A+1}{4}-\frac{A-1}{2}\left(\cos \theta t+\frac{1}{2} \cos \phi t-\sin \frac{1}{2} \phi t\right)
$$

This function defines time-dependent head values in the "recharge strip" 


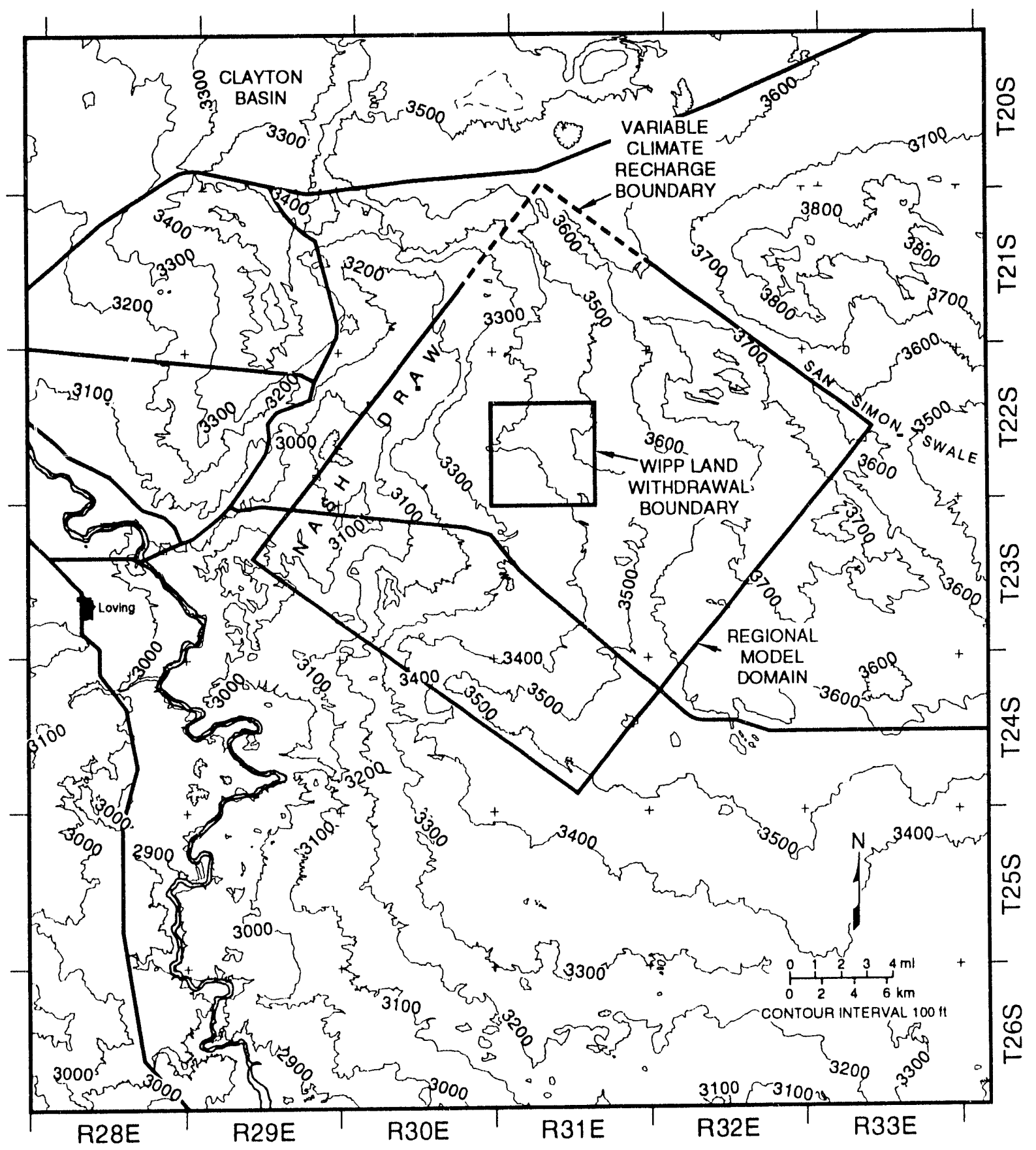

TA1.6342.787-5

Figure 3. Topographic map of the WIPP area showing the boundaries of the regional groundwater flow model used in the 1991 performance assessment (modified from WIPP PA Division, 1991b). 
where
$h_{\mathrm{f}}(\mathrm{t})=$ head $(\mathrm{m})$ in selected boundary cells in the Culebra at time $\mathrm{t}$,
$h_{p}=$ estimated head $(m)$ in selected boundary cells in the Culebra now,
A = recharge amplitude factor (dimensionless), as described below,
$\theta=$ frequency $(\mathrm{Hz})$ for Pleistocene glaciations,
$\phi \quad=\quad$ frequency $(\mathrm{Hz}$ ) for second-order climatic fluctuations, and
$\mathrm{t}=$ time (sec) after decommissioning of the WIPP.

Figure 4 shows values of the function at 1000-yr time intervals, as implemented in the 1991 WIPP PA.

This function is not used to predict future climates, but rather is designed to provide a simple way to examine the influence of possible climatic changes during the next $10,000 \mathrm{yr}$. Variable parameters permit examining sensitivity to both the frequency and amplitude of climatic change.

Periodicity of the function is controlled by two terms, $\theta$ and $\phi$, that can be adjusted to approximate the periodicities observed in the paleoclimatic record. In preliminary PAs to date, fixed values have been used for these two parameters, yielding a glacial periodicity of $60,000 \mathrm{yr}$ and a second-order periodicity of $3000 \mathrm{yr}$. If performance is believed to be sensitive to the frequency of climatic change, different values for these parameters can be used in future analyses.

Amplitude of the function is controlled by A, which can be scaled appropriately for the groundwater-flow model parameter to be varied. For the $1991 \mathrm{PA}$, this parameter was varied from 1 to 1.16 . The minimum value, 1 , results in no change in boundary head values in the "recharge strip" during the entire $10,000 \mathrm{yr}$ period. The maximum value, 1.16. causes head values to rise from their initial (present) elevation (e.g., $880 \mathrm{~m}$ in the northernmost cell) to the elevation of the ground surface $(1030 \mathrm{~m}$ in the northernmost cell) at the end of the 10,000 period (Figure 4). Geologic evidence suggests that this increase in head may not be unrealistic: fossil spring deposits at lower elevations in the region indicate discharge from a water table at the ground surface during the late Pleistocene (Bachman, 1981; 1987). Relatively low topographic relief in the region precludes head rising significantly above the ground surface.

\section{Discussion}

In keeping with the probabilistic requirements of 40 CFR 191, consequence modeling for WIPP PA is performed using a Monte Carlo approach that relies on multiple realizations of system performance using deterministic models of physical processes (WIPP PA Department, 1992a,b). Values for uncertain parameters are selected using a Latin hypercube sampling strategy (McKay et al., 1979) from distributions based on available data, and each realization uses a separate input vector of sampled parameter values. The methodology is well-suited for conducting uncertainty and sensitivity analyses that provide quantitative and qualitative insights about the potential variability in model results caused by uncertainty in specific input data (Helton et al., 1991, 1992; Helton, 1993).

The recharge amplitude factor, A, defined above for Equation 1, was one of 45 parameters sampled for use in 60 realizations in the 1991 preliminary PA (Helton et al., 1992) and one of 49 such parameters used in 70 realizations in the 1992 PA (WIPP PA Department, 1993a). Analyses were performed for scenarios involving a 


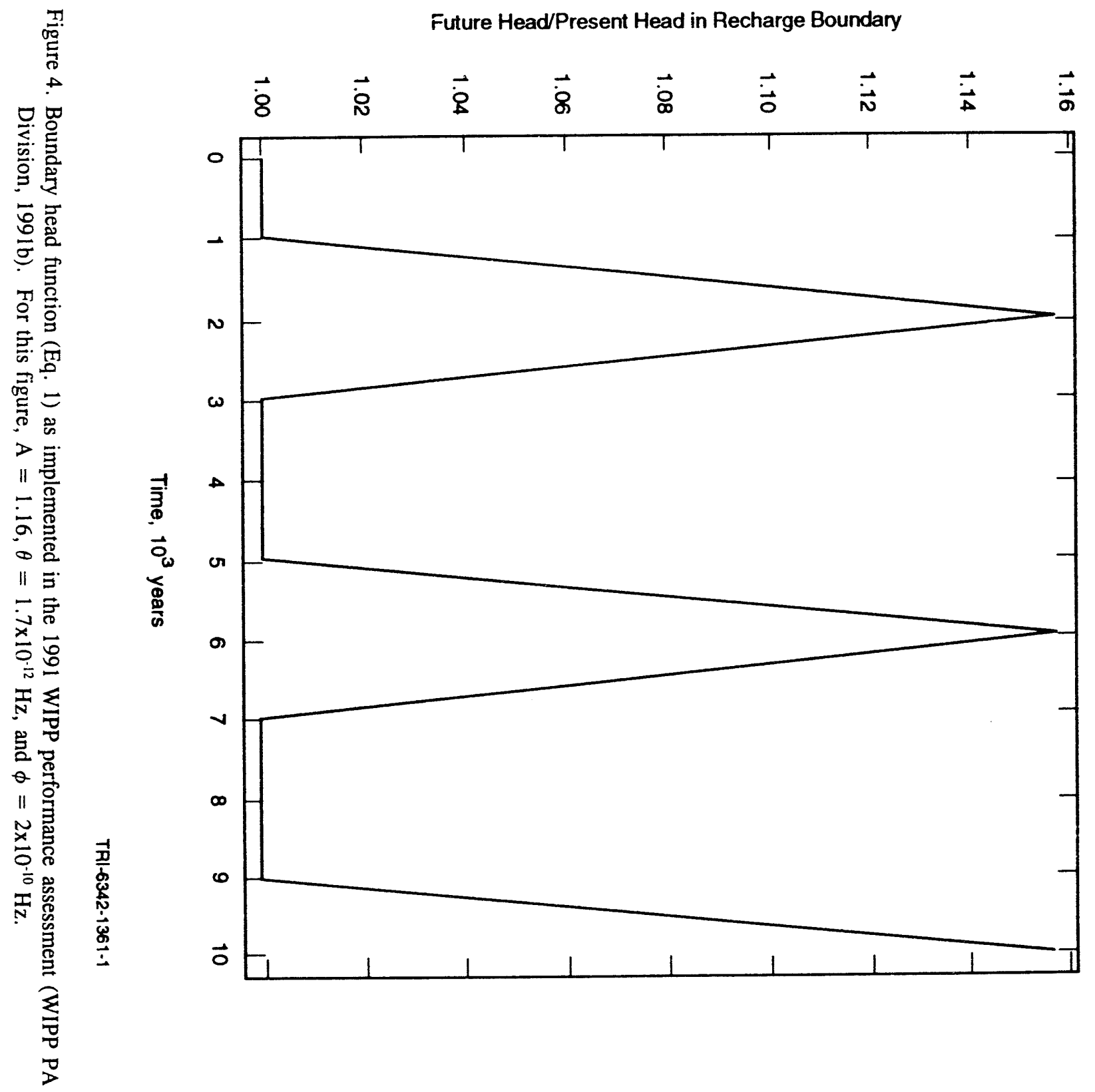


single intruding borehole and two intruding boreholes. In both 1991 and 1992, simulations were repeated using the full suite of realizations for eitch of several conceptual models for radionuclide tran port in the Culebra. The choice of transport model for use in a final PA will be made after additional data are obtained (US DOE, 1993). Cases considered to date include transport in a single-porosity, fracture-only medium and transport in a dual-porosity medium which allowed diffusion into the pore volume of the dolomite matrix. Cases were considered both with and without chemical retardation of radionuclides by sorption. Computational modeling, including discussion of the computer codes used, and the results of these analyses are described in detail elsewhere (WIPP PA Division 1991b, Helton et al., 1992; WIPP PA Department 1992b, WIPP PA Department, 1993a).

Variability in the recharge amplitude factor contributed significantly to variability $\mathrm{n}$ total releases only for the conceptual model that included dual-porosity transport without chemical retardation (Helton et al., 1992). Even in this case, regression analysis shows variation in boundary head values to have been a minor contributor to overall variability in model outcomes, ranking below parameters used to describe radionuclide solubility in the source term, permeability of the borehole pathway from the repository to the Culebra, and fracture spacing in the Culebra.

Two analyses were conducted as part of the 1991 PA that specifically examined the importance of houndary head variations by using fixed minimum (1.00) and maximum (1.16) values for the recharge amplitude factor (Helton et al., 1992). The full suite of 60 realizations were repeated for each analysis with sampled values used for all other parameters, resulting in two sets of outcomes which were in all ways comparable except for the value used for A. Results are shown in Figure 5 for both single-porosity and dual-porosity transport with chemical retardation. For all but a few of the single-porosity realizations, using the maximum recharge factor has essentially no effect on total releases. This lack of sensitivity apparently occurs because single-porosity transport is rapid enough that most of the long-lived radionuclides (e.g., U) that enter the Culebra reach the accessible environment within $10,000 \mathrm{yr}$ regardless of the head gradient. For the relatively slower dual-porosity transport, the maximum recharge factor increased releases for essentially all realizations in which subsurface releases occurred.

\section{Conclusions}

For preliminary comparison with requirements of 40 CFR 191, performance estimates are displayed as complementary cumulative distribution functions (CCDFs) that indicate the probability of exceeding various levels of cumulative radionuclide releases to the accessible environment. Because the modeling system and database are incomplete, no CCDFs presented to date in WIPP PA are suitable for compliance evaluations. Regulatory limits are commonly displayed, however, on preliminary CCDFs to provide guidance to the Project and to assist in identifying those areas in which uncertainty has the potential to affect compliance.

Figure 6 is a composite display of mean CCDFs that shows the relative importance of the recharge factor in the 1991 PA (Helton et al., 1992). Estimated performance is shown for three altemative cases: transport in a single-porosity medium with chemical retardation and sampled values for the recharge factor, transport in a dualporosity medium with chemical retardation and the maximum recharge factor used in all realizations, and transport in a dual-porosity medium with chemical retardation and the minimum (i.e., present) recharge factor used in all realizations. Except for those parameters used to describe the alternative trarsport cases, all parameter values were the same for each case. Results do not include releases at the ground surface during drilling, and therefore are an incomplete measure of overall performance. Limits specified by 40) CFR $191 \mathrm{~B}$ are given only for reference. 

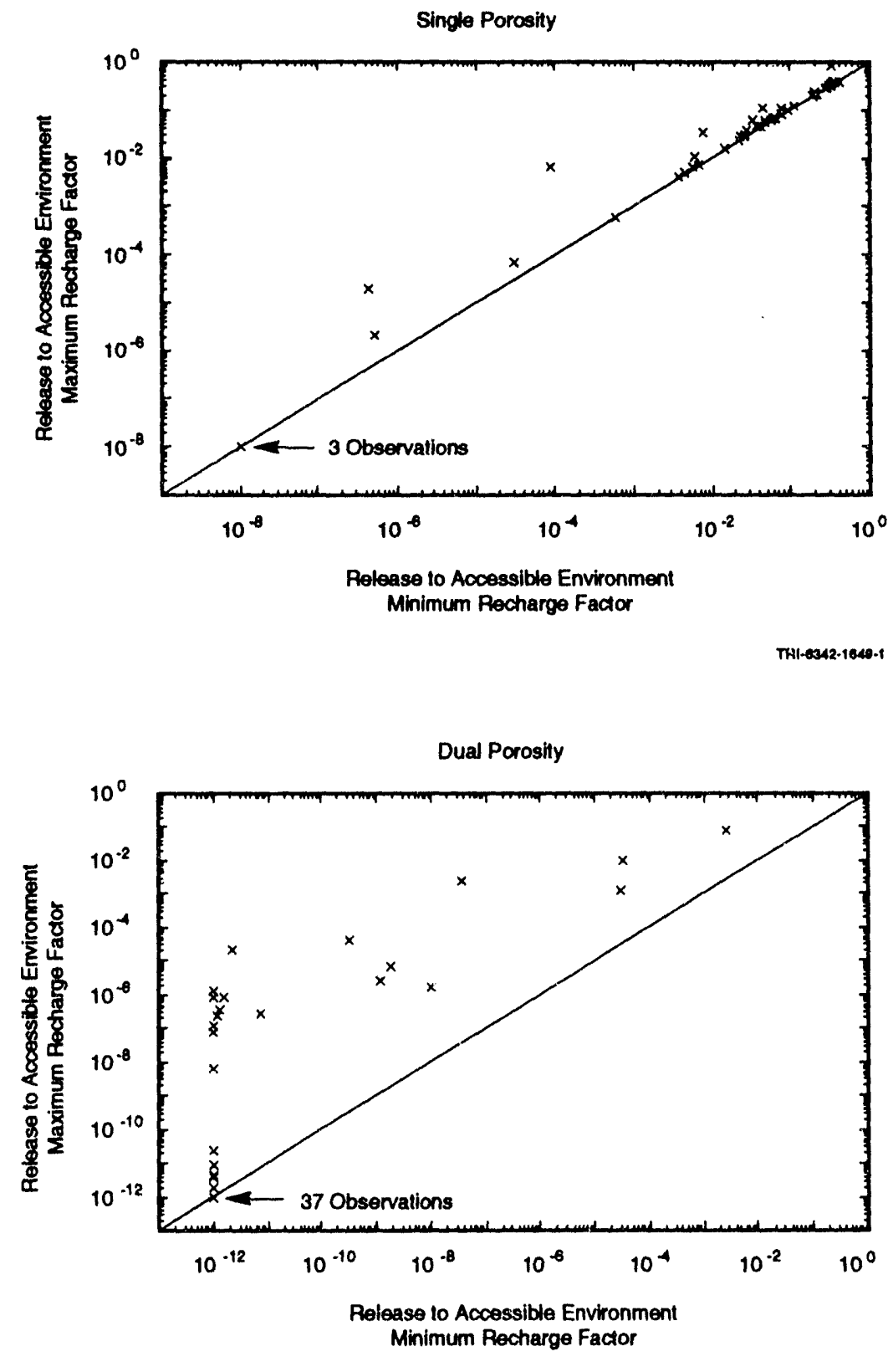

Figure 5. Scatterplots showing 10,000-yr cumulative radionuclide releases to the subsurface boundary of the accessible environment 60 for realizations using minimum and maximum values for the recharge amplitude factor (Helton et al., 1992). Releases are normalized to the total inventory, as specified by 40 CFR 191. Releases are shown for single (top) and dual (bottom) porosity conceptual models for radionuclide transport including chemical retardation. Both plots show releases from scenarios involving two intrusions into the same panel $1000 \mathrm{yr}$ after decommissioning (see WIPP PA Division [1991b] for a discussion of scenario definitions). Normalized releases below $10^{-8}$ (above) and $10^{-12}$ (below) are plotted
at those values. 


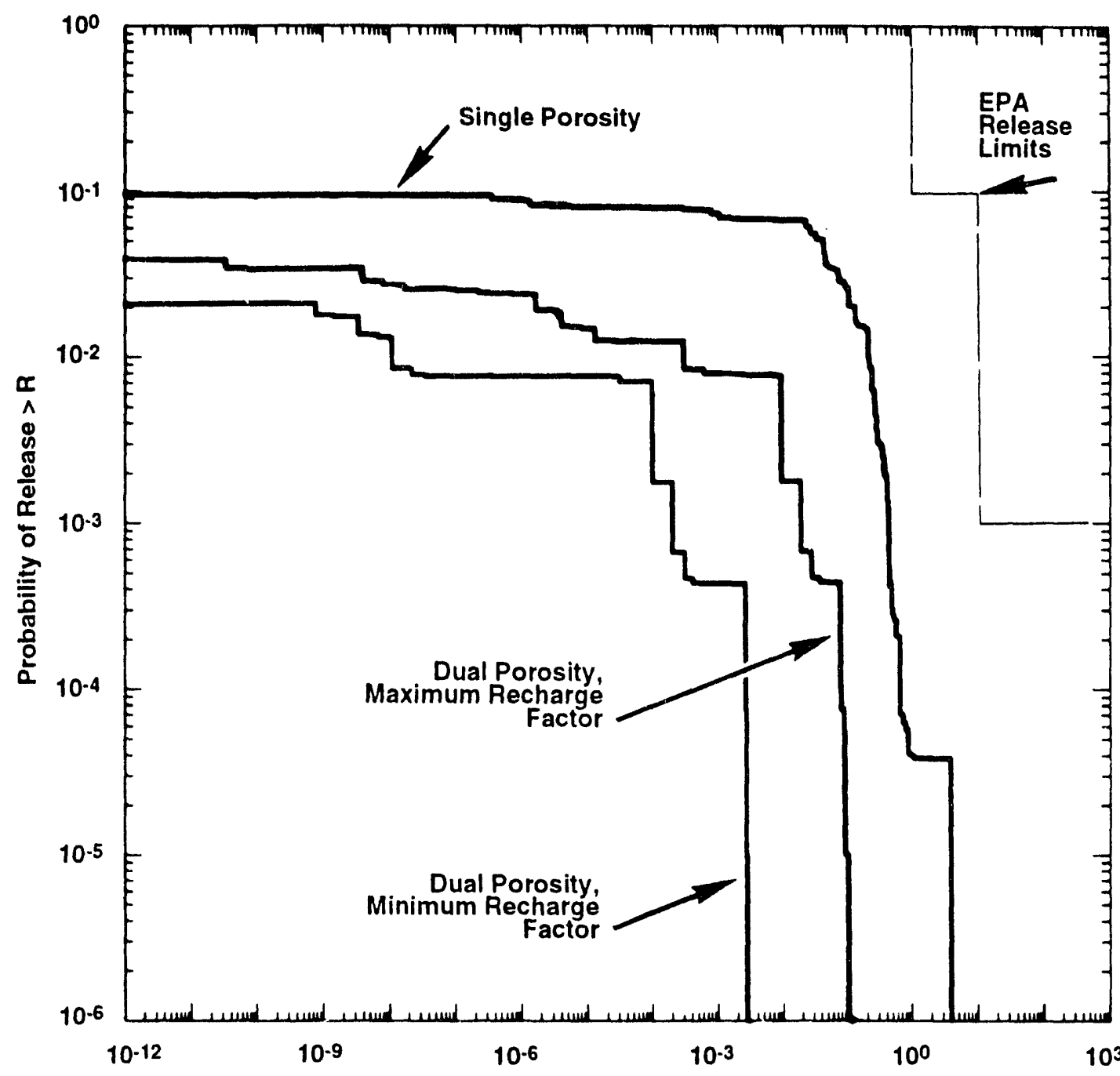

Release to Accessible Environment, $R$

TRI-6342.3805.0

Figure 6. Mean CCDFs showing estimated performance of the WIPP for subsurface releases only following intrusions at $1000 \mathrm{yr}$ after decommissioning (Helton et al., 1992). Releases are normalized to the total inventory, as specified by 40 CFR 191. Curves are shown for three cases: single-porosity transport with sampled values for the recharge factor, dual-porosity transport with the maximum value for the recharge factor, and dual-porosity transport with the minimum value for the recharge factor. All cases include chemical retardation. EPA limits are shown for reference only. Results here are not suitable for direct comparison to regulatory limits because they are preliminary (i.e., based on an incomplete modeling system and database) and because they do not include releases at the ground surface during drilling. 
Single-porosity transport results in the largest releases and the CCDF closest to the EPA limits. Separate curves are not shown for the single-porosity extreme climate cases because, as shown in Figure 5, changing the recharge factor has essentially no effect on the largest releases that determine the location of the mean CCDF. Varying boundary head values within this range does not affect regulatory releases if transport occurs in a singleporosity medium.

The iwo mean CCDFs shown for dual-porosity transport are significantly further from the EPA limits than the CCDF for the single-porosity case. Allowing boundary head values to rise in response to climatic change does result in an increase in estimated releases, but not sufficiently to affect compliance.

Although all results shown here are conditional on the assumptions used in the analyses, and may change as flow and transport models are improved, the conclusion that climate change is unlikely to affect compliance appears robust. The uncertainty remaining about the correct conceptual models for both climatically-varying recharge and radionuclide transport in the Culebra is substantial, but as long as releases calculated with extreme head elevations and the least favorable transport model considered remain below the EPA limits, climate change alone will not lead to regulatory violations. Defensibility of this conclusion will depend in part on improved understanding of regional flow. 


\section{REFERENCES}

Bachman, G.O. 1981. Geology of Nash Draw, Eddy County, New Mexico. Open-File Report 81-31. United States Geological Survey, Denver, CO.

Bachman, G.O. 1987. Karst in Evaporites in Southeastern New Mexico. SAND86-7078. Sandia National Laboratories, Albuquerque, NM.

Beauheim, R.L., and R.M. Holt. 1990. Hydrogeology of the WIPP Site, pp. 131-179. In: Geological and Hydrological Studies of Evaporites in the Northern Delaware Basin for the Waste Isolation Pilot Plant (WIPP), New Mexico. Geological Society of America 1990 Annual Meeting Field Trip \#14 Guidebook. Dallas Geological Society, Dallas, TX.

Bertram-Howery, S.G., M.G. Marietta, R.P. Rechard, P.N. Swift, D.R. Anderson, B.L. Baker, J.E. Bean, Jr., W. Beyeler, K.F. Brinster, R.V. Guzowski, J.C. Helton, R.D. McCurley, D.K. Rudeen, J.D. Schreiber, and P. Vaughn. 1990. Preliminary Comparison with 40 CFR Part 191, Subpart B for the Waste Isolation Pilot Plant, December 1990. SAND90-2347. Sandia National Laboratories, Albuquerque, NM.

Brinster, K.F. 1991. Preliminary Geohydrologic Conceptual Model of the Los Medaños Region Near the Waste Isolation Pilot Plant for the Purpose of Performance Assessment. SAND89-7147. Sandia National Laboratories, Albuquerque, NM.

Cole, F.W. 1975. Introduction to Meteorology. 2nd edition. John Wiley and Sons, New York, NY.

COHMAP (Cooperative Holocene Mapping Project) Members. 1988. Climatic changes of the last 18,000 years: observations and model simulations. Science 241:1043-1052.

Corbet, T. F., and M. G. Wallace. 1993. Post Pleistocene patterns of shallow groundwater flow in the Delaware Basin, southeastern New Mexico and west Texas, pp. 321-325. In: New Mexico Annual Field Conference Guidebook, Carlsbad Region, Permian Basin, New Mexico and West Texas. J.W. Hawley and D.W. Love (eds.).

Davies, P.B. 1989. Variable-Density Ground-Water Flow and Paleohydrology in the Waste Isolation Pilot Plant (WIPP) Region. Southeastern New Mexico. Open-File report 88-490. United States Geological Survey, Albuquerque, NM.

Hays, J.D., J. Imbrie, and N.J. Shackleton. 1976. Variations in the Earth's orbit: pacemaker of the Ice Ages. Science 194:1121-1132.

Helton, J.C. 1993. Risk, uncertainty in risk, and the EPA release limits for radioactive waste disposal. (SAND911255J). Nuclear Technology 101:18-39. 
Helton, J.C., J.W. Garner, R.D. McCurley, and D.K. Rudeen. 1991. Sensitivity Analysis Techniques and Results for Performance Assessment at the Waste Isolation Pilot Plant. SAND90-7103. Sandia National Laboratories, Albuquerque, NM.

Helton, J.C., J.W. Garner, R.P. Rechard, D.K. Rudeen, and P.N. Swift. 1992. Preliminary Comparison with 40 CFR Part 191, Subpart B for the Waste Isolation Pilot Plant, December 1991 - Volume 4: Uncertainty and Sensitivity Analysis Results. SAND91/0893/4. Sandia National Laboratories, Albuquerque, NM.

Houghton, J.T., G.J. Jenkins, and J.J. Ephraums. 1990. Climate Change: The IPCC Scientific Assessment. Cambridge University Press, New York, NY.

Hunter, R.L. 1985. A Regional Water Balance for the Waste Isolation Pilot Plant (WIPP) Site and Surrounding Area. SAND84-2233. Sandia National Laboratories, Albuquerque, NM.

Imbrie, J. 1985. A theoretical framework for the Pleistocene Ice Ages. Journal of the Geological Society 142:417432.

Imbrie, J., and J.Z. Imbrie. 1980. Modeling the climatic response to orbital variations. Science 207:943-953.

Imbrie, J., J.D. Hays, D.G. Martinson, A. McIntyre, A.C. Mix, J.J. Morley, N.G. Pisias, W.L. Prell, and J.J. Shackleton. 1984. The orbital theory of Pleistocene climate: support from a revised chronology of the marine $\delta^{18} \mathrm{O}$ record, pp. 269-305, Part 1. In: Milankovitch and Climate, Proceedings of the NATO Advanced Research Workshop on Milankovitch, Palisades, NY, November 30-December 4, 1982. A.L. Berber, J. Imbrie, J. Hays, G. Kukla, and B. Saltzman (eds.). D. Reidel Publishing Co., Boston MA.

Lambert, S.J. 1991. Isotopic Constraints on the Rustler and Dewey Lake Groundwater Systems, pp.5-1 through 5-79. In: Hydrogeochemical Studies of the Rustler Formation and Related Rocks in the Waste Isolation Pilot Plant Area, Southeastern New Mexico. M.D. Siegel, S.J. Lambert, and K.L. Robinson (eds.). SAND88-0196. Sandia National Laboratories, Albuquerque, NM.

Lambert, S.J., and J.A. Carter. 1987. Uranium-Isotope Systematics in Groundwaters of the Rustler Formation, Northern Delaware Basin, Southeastern New Mexico, 1: Principles and Preliminary Results. SAND87-0388. Sandia National Laboratories, Albuquerque, NM.

McKay, M.D., R.J. Beckman, and W.J. Conover. 1979. A comparison of three methods for selecting values of input variables in the analysis of output from a computer code. Technometrics 21:239-245.

Mercer, J.W. 1983. Geohydrology of the Proposed Waste Isolation Pilot Plant Site, Los Medaños Area, Southeastern New Mexico. Water-Resources Investigations Report 83-4016. United States Geological Survey, Albuquerque, NM. 
Milankovitch, M. 1941. Canon of Insolation and the Ice-Age Problem. Koniglich Serbische Akademie, Beograd. (English translation by the Israel Program for Scientific Translations; published by the United States Department of Commerce and the National Science Foundation, Washington, D.C.).

Mitchell, J.F.B. 1989. The "Greenhouse Effect" and climate change. Reviews of Geophysics 27:115-139.

Public Law 102-579. 1992. Waste Isolation Pilot Plant Land Withdrawal Act.

Rechard, R.P., H. Iuzzolino, and J.S. Sandha. 1990. Data Used in Preliminary Performance Assessment of the Waste Isolation Pilot Plant (1990). SAND89-2408. Sandia National Laboratories, Albuquerque, NM.

Sandia WIPP Project. 1992. Preliminary Performance Assessment for the Waste Isolation Pilot Plant, December 1992 - Volume 3: Model Parameters. SAND92-0700/3. Sandia National Laboratories, Albuquerque, NM.

Schlesinger, M.E., and J.F.B. Mitchell. 1987. Climate model simulations of the equilibrium climatic response to increased carbon dioxide. Reviews of Geophysics 25:760-798.

Swift, P.N. 1991. Climate and recharge variability parameters for the 1991 WIPP PA calculations, pp. A-107 through A-122. In: Preliminary Comparison with 40 CFR Part 191, Subpart B for the Waste Isolation Pilot Plant, December 1991 - Volume 3: Reference Data. WIPP PA Division (author). SAND91-0893/3. Sandia National Laboratories, Albuquerque, NM.

Swift, P.N. 1993. Long-term climate variability at the Waste Isolation Pilot Plant, Southeastern New Mexico, USA. (SAND91-7055J). Environmental Management 17:83-97.

US DOE (United States Department of Energy). 1980. Final Environmental Impact Statement: Waste Isolation Pilot Plant. DOE/EIS-0026. United States Department of Energy, Washington, D.C.

US DOE (United States Department of Energy). 1993. Test Phase Plan for the Waste Isolation Pilot Plant. DOE/WIPP 89-011, Rev. 1. United States Department of Energy WIPP Project Integration Office, Albuquerque, NM.

US EPA (United States Environmental Protection Agency). 1985. 40 CFR Part 191: environmental radiation protection standards for the management and disposal of spent nuclear fuel, high-level and transuranic radioactive wastes, final rule. Federal Register 50:38066-38089.

University of New Mexico. 1989. New Mexico Statistical Abstract 1989. Bureau of Business and Economic Research, University of New Mexico, Albuquerque, NM.

Washington, W.M., and G.A. Meehl. 1984. Seasonal cycie experiment on the climate sensitivity due to doubling of $\mathrm{CO}_{2}$ with an atmospheric general circulation model coupled to a simple mixed-layer ocean model. Journal of Geophysical Research 89:9475-9503. 
Wilson, C.A., and J.F.B. Mitchell. 1987. A doubled $\mathrm{CO}_{2}$ climate sensitivity experiment with a global climate model including a simple ocean. Journal of Geophysical Research 92:13,315-13,343.

WIPP PA (Performance Assessment) Department. 1992a. Preliminary Performance Assessment for the Waste Isolation Pilot Plant, December 1992 - Volume 1: Third Comparison with 40 CFR 191, Subpart B. SAND920700/1. Sandia Naticnal Laboratories, Albuquerque, NM.

WIPP PA (Performance Assessment) Department. 1992b. Preliminary Performance Assessment for the Waste Isolation Pilot Plant, December 1992 - Volume 2: Technical Basis. SAND92-0700/2. Sandia National Laboratories, Albuquerque, NM.

WIPP PA (Performance Assessment) Department. 1993a. Preliminary Performance Assessment for the Waste Isolation Pilot Plant, December 1992 - Volume 4: Uncertainty and Sensitivity Analyses for 40 CFR 191, Subpart B. SAND92-0700/4. Sandia National Laboratories, Albuquerque, NM.

WIPP PA (Performance Assessment) Department. 1993b. Preliminary Performance Assessment for the Waste Isolation Pilot Plant, December 1992 - Volume 5: Uncertainty and Sensitivity Analyses of Gas and Brine Migration for Undisturbed Performance. SAND92-0700/5. Sandia National Laboratories, Albuquerque, NM.

WIPP PA (Performance Assessment) Division. 1991a. Preliminary Comparison with 40 CFR Part 191, Subpart B for the Waste Isolation Pilot Plant - Volume 1: Methodology and Results. SAND91-0893/1. Sandia National Laboratories, Albuquerque, NM.

WIPP PA (Performance Assessment) Division. 1991b. Preliminary Comparison with 40 CFR Part 191, Subpart B for the Waste Isolation Pilot Plant - Volume 2: Probability and Consequence Modeling. SAND91-0893/2. Sandia National Laboratories, Albuquerque, NM.

WIPP PA (Performance Assessment) Division. 1991c. Preliminary Comparison with 40 CFR Part 191, Subpart B for the Waste Isolation Pilot Plant - Volume 3: Reference Data. SAND91-0893/3. Sandia National Laboratories, Albucquerque, NM. 


\section{PERFORMANCE ASSESSMENT DISTRIBUTION LIST}

(Send Distribution list changes to M.M. Gruebel, Dept. 6342, Sandia

National Laboratories, PO Box 5800, Albuquerque, NM 87185-1328)

\section{Federal Agencies}

US Department of Energy (6)

Office of Civilian Radioactive Waste Management

Attn: Deputy Director, RW-2

Associate Director, RW-10/50

Office of Program and

Resources Management

Office of Contract Business

Management

Director, RW-22, Analysis and

Verification Division

Associate Director, $\mathrm{RW}-30$

Office of Systems and

Compliance

Associate Director, $\mathrm{RW}-40$

Office of Storage and

Transportation

Director, RW-4/5

Office of Strategic Planning and International Programs Office of External Relations

Forrestal Building

Washington, DC 20585

US Department of Energy

Albuquerque Operations office

Attn: National Atomic Museum Library

PO Box 5400

Albuquerque, NM 87185

US Department of Energy (2)

Office of Environmental Restoration and Waste Management

Attn: Director, EM-1

C. Frank, EM-50

Washington, DC 20585

US Department of Energy (3)

Office of Environmental Restoration and Waste Management

Attn: M. Frei, EM-34 / Trevion II

Director, Waste Management Projects

Washington, DC 20585-0002

US Department of Energy

Office of Environmental Restoration and Waste Management

Attn: J. Lytle, EM-30 / Trevion II

Washington, DC 20585-0002
US Department of Energy

Office of Environmental Restoration and Waste Management

Attn: S. Schneider, EM-342

Trevion II

Washington, DC 20585-0002

US Department of Energy (3)

WIPP Task Force

Attn: G.H. Daly

S. Fucigna

B. Bower

12800 Middlebrook Rd., Suite 400

Germantown, MD 20874

US Department of Energy (4)

Office of Environment, Safety and

Health

Attn: R.P. Berube, EH-20

C. Borgstrom, EH-25

R. Pelletier, EH-231

K. Taimi, EH-232

Washington, DC 20585

US Department of Energy (6)

WIPP Project Integration Office

Attn: S. Alcorn

W.J. Arthur III

J. Coffey

L.W. Gage

P.J. Higgins

D.A. Olona

PO Box 5400

Albuquerque, NM 87115-5400

US Department of Energy (2)

WIPP Project Integration Satellite

office

Attn: R. Batra

R. Becker

PO Box 3090, Mail Stop 525

Carlsbad, NM 88221-3090

US Department of Energy (10)

WIPP Project Site Office (Carlsbad)

Attn: A. Hunt (4)

V. Daub (4)

$J$. Lippis

$\mathrm{K}$. Hunter

PO Box 3090

Carlsbad, NM 88221-3090 
US Department of Energy

Research \& Waste Management Division Attn: Director

PO Box E

Oak Ridge, TN 37831

US Department of Energy (2)

Idaho Operations office

Fuel Processing and Waste

Management Division

785 DOE Place

Idaho Falls, ID 83402

US Department of Energy

Savannah River Operations office

Defense Waste Processing

Facility Project Office

Attn: W.D. Pearson

PO Box A

Aiken, SC 29802

US Department of Energy

Richland Field office

Attn: R.F. Guercia

PO Box 550 / R3-80

Richland, WA 99352

US Department of Energy

Office of Geologic Disposal

Yucca Mountain Project Office

Attn: Associate Director, KW-20

PO Box 98608

Las Vegas, NV 89193-8608

US Department of Energy (3)

Nevada Operations Office

Attn: J.R. Bol and

D. Livingston

P.K. Fitzsimmons

2753 S. Highland Drive

Las Vegas, NV 89183-851.8

US Department of Energy (2)

Technical Information Center

PO Box 62

Oak Ridge, TN 37831

US Department of Energy (2)

Chicago Operations office

Attn: J.C. Haugen

9800 South Cass Avenue

Argonne, IL 60439
US Department of Energy

Rocky Flats Area Office

Attn: W.C. Rask

G. Huffman

T. Lukow

PO Box 928

Golden, CO 80402-0928

US Department of Energy

Los Alamos Area Office

52835 th Street

Los Alamos, NM 87544

US Department of Energy

Dayton Area Office

Attn: R. Grandfield

PO Box 66

Miamisburg, OH 45343-0066

US Bureau of Land Management

Carlsbad office

101 E. Mermod

Carlsbad, NM 88220

US Bureau of Land Management

New Mexico State office

PO Box 1449

Santa Fe, NM 87507

US Environmental Protection Agency (2)

Radiation Protection Programs

Attn: M. Oge

ANR -460

Washington, DC 20460

US Environmental Protection

Agency, Region 6

Attn: C. Byrum, 6T-ET

1445 Ross Ave.

Dallas, TX 75202

US Geological Survey (2)

Water Resources Division

Attn: C. Peters

4501 Indian School NE

Suite 200

Albuquerque, NM 87110

US Nuclear Regulatory Commission Division of Waste Management

Attn: H. Marson

Mail Stop 4-H-3

Washington, DC 20555 
US Nuclear Regulatory Commission (4) Advisory Committee on Nuclear Waste Attn: D. Moeller

M.J. Steindler

P.W. Pomeroy

W.J. Hinze

7920 Norfolk Ave.

Bethesda, MD 20814

Defense Nuclear Facilities Safety

Board

Attn: D. Winters

625 Indiana Ave. NW

Suite 700

Washington, DC 20004

Nuclear Waste Technical Review Board

Attn: Library (2)

1100 Wilson Blvd.

Suite 910

Arlington, VA 22209-2297

\section{State Agencies}

New Mexico Bureau of Mines and Mineral Resources

Socorro, NM 87801

New Mexico Energy, Minerals and

Natural Resources Department

Attn: Librarian

2040 South Pacheco

Santa Fe, NM 87505

New Mexico Energy, Minerals and

Natural Resources Department

New Mexico Radioactive Task Force (2)

(Governor's WIPP Task Force)

Attn: A. Lockwood, Chairman

C. Wentz, Policy Analyst

2040 South Pacheco

Santa Fe, NM 87505

Bob Forrest

Mayor, City of Carlsbad

PO Box 1569

Carlsbad, NM 88221

Carlsbad Department of Development

Executive Director

Attn: C. Bernard

PO Box 1090

Carlsbad, NM 88221
New Mexico Environment Department Secretary of the Environment (3)

Attn: J. Espinosa

PO Box 968

1190 St. Francis Drive

Santa Fe, NM 87503-0968

New Mexico Environment Department

Attn: P. McCasland

WIPP Project Site office

PO Box 3090

Car1sbad, NM 88221-3090

New Mexico State Engineer's Office

Attn: M. Chudnoff

PO Box 25102

Santa Fe, NM 87504-5102

Environmental Evaluation Group (5)

Attn: R. Neill

7007 Wyoming Blvd. NE, Suite F-2

Albuquerque, NM 87109

\section{Advisory Committee on Nuclear Facility Safety}

John F. Ahearne

Executive Director, Sigma Xi

99 Alexander Drive

Research Triangle Park, NC 27709

James E. Martin

109 Observatory Road

Ann Arbor, MI 48109

\section{WIPP Committee, National Research Council's Board on Radioactive Waste Management}

National Research Council (2)

Board on Radioactive Waste Management

Attn: C.A. Anderson

I. B. Alterman

2101 Constitution Ave. NW

Harris Bldg. HA 456

Washington, DC 20418

Howard Adler

Oxyrase, Inc.

11020 Solway School Rd.

Knoxville, TN 37931

John 0. Blomeke

3833 Sandy Shore Drive

Lenoir City, TN 37771-9803 
John D. Bredehoeft

Western Region Hydrologist

Water Resources Division

US Geological Survey (M/S 439)

345 Middlefield Road

Menlo Park, CA 94025

Fred M. Ernsberger

1325 NW Tenth Ave.

Gainsville, FL 32605

Rodney C. Ewing

Department of Geology

University of New Mexico

Albuquerque, NM 87131

Charles Fairhurst

Department of Civil and Mineral

Engineering

University of Minnesota

500 Pillsbury Dr. SE

Minneapolis, MN 55455-0220

B. John Garrick

PLG, Incorporated

4590 MacArthur Blvd., Suite 400

Newport Beach, CA 92660-2027

Leonard F. Konikow

US Geological Survey

431 National Center

Reston, VA 22092

Jeremiah O'Driscoll

Jody, Incorporated

505 Valley Hill Drive

Atlanta, GA 30350

Christopher G. Whipple

ICF Kaiser Engineers

1800 Harrison St. 7th Floor

Oakland, CA 94612-3430

Thomas A. Zordan

Zordan Associates, Inc.

3807 Edinburg Dr.

Murrysville, PA 15668

\section{Performance Assessment Peer Review Panel}

G. Ross Heath

College of Ocean \& Fishery Sciences

University of Washington

583 Henderson $\mathrm{Ha} 11$, $\mathrm{HN}-15$

Seattle, WA 98195
Thomas H. Pigford

Department of Nuclear Engineering

4159 Etcheverry Hall

University of California

Berkeley, CA 94720

Thomas A. Cotton

JK Research Associates, Inc.

4429 Butterworth P1ace NW

Washington, DC 20016

Robert J . Budnitz

President, Future Resources

Associates, Inc.

2000 Center Street

Suite 418

Berkeley, CA 94704

C. John Mann

Department of Geology

245 Natural History Bldg.

1301 West Green Street

University of Illinois

Urbana, IL 61801

Frank W. Schwartz

Department of Geology and Mineralogy

The Ohio State University

Scott Hall

1090 Carmack Rd.

Columbus, $\mathrm{OH} \quad 43210$

\section{National Laboratories}

Argonne National Laboratory (2)

Attn: A. Smith

D. Tomasko

9700 South Cass, Bldg. 201

Argonne, IL 60439

Battelle Pacific Northwest

Laboratory (2)

Attn: S. Bates

R.E. Westerman MSIN P8-44

Battelle Boulevard

Richland, WA 99352

Idaho National Engineering

Laboratory (2)

Attn: H. Loo

R. Klinger

Mail Stop 5108

Idaho Falls, ID 83403-4000 
Los Alamos National Laboratory (5)

Attn: B. Erdal, INC-12

M. Ennis, HS-12

Mail Stop J 900

S. Kosiewicz, EM-7

Mail Stop J595

L. Soholt, EM-13

Mail Stop M992

$\mathrm{J}$. Wenze1, HS-12

Mail Stop K482

PO Box 1663

Los Alamos, NM 87545

Oak Ridge National Laboratory

Transuranic Waste Manager

Attn: D.W. Turner

B1dg. 3047

PO Box 2008

Oak Ridge, TN 37831-6060

Pacific Northwest Laboratory

Attn: B. Kennedy

PO Box 999

Richland, WA 99352

Westinghouse-Savannah River

Technology Center (4)

Attn: N. Bibler

J.R. Harbour

M.J. Plodinec

G.G. Wicks

Aiken, SC 29802

\section{Corporations/Members of the Public}

Battelle Memorial Institute

Attn: R. Root

J. Kircher

505 Marquette NW, Suite 1

Albuquerque, NM 87102

Benchmark Environmental Corp.

Attn: C. Frederickson

4501 Indian School NE, Suite 105

Albuquerque, NM 87110

Beta Corporation Int.

Attn: E. Bonano

6613 Esther NE

Albuquerque, NM 87109

City of Albuquerque

Public Works Department

Utility Planning Division

Attn: W.K. Summers

PO Box 1293

Albuquerque, NM 87103
Deuel and Associates, Inc.

Attn: R.W. Prindle

7208 Jefferson NE

Albuquerque, NM 871.09

Disposal Safety, Inc.

Attn: B. Ross

1660 L Street NW, Suite 314

Washington, DC 20036

Ecodynamics ( 3 )

Attn: P. Roache

R. Blaine

K. Economy

PO Box 9229

Albuquerque, NM 87119-9229

EG \& G Idaho (3)

1955 Fremont Street

Attn: C. Atwood

C. Hertzler

T.I. Clements

Idaho Falls, ID 83415

Geomatrix

Attn: K. Coppersmith

100 Pine St., Suite 1000

San Francisco, CA 94111

Golder Associates, Inc.

Attn: R. Kossik

4104 148th Avenue NE

Redmond, WA 98052

John Hart and Associates, P.A.

Attn: J.S. Hart

2815 Candelaria Road NW

Albuquerque, NM 87107

John Hart and Associates, P.A.

Attn: K. Lickliter

400-C 8th St. NW

Tacoma, WA 98439

INTERA, Inc .

Attn: A.M. LaVenue

1650 University Blvd. NE, Suite 300

Albuquerque, NM 87102

INTERA, Inc .

Attn: J.F. Pickens

6850 Austin Center Blvd., Suite 300

Austin, TX 78731 
INTERA, Inc .

Attn: W. Stensrud

PO Box 2123

Carlsbad, NM 88221

INTERA, Inc .

Attn: W. Nelson

101 Convention Center Dr.

Suite 540

Las Vegas, NV 89109

IT Corporation (2)

Attn: R.F. Mckinney

$$
\text { J . Myers }
$$

Regional office, Suite 700

5301 Central Avenue NE

Albuquerque, NM 87108

Lawrence Berkeley Laboratory

Attn: J . Long

Building $50 \mathrm{E}$

Berkeley, CA 94720

MAC Technical Services Co.

Attn: D.K. Duncan

8418 Zuni Road SE, Suite 200

Albuquerque, NM 87108

Newman and Holtzinger

Attn: C. Mallon

1615 L Street NW, Suite 1000

Washington, DC 20036

$\mathrm{RE} / \mathrm{SPEC}$, Inc. (2)

Attn: W. Coons

4775 Indian School NE, Suite 300

Albuquerque, NM 87110

$\mathrm{RE} / \mathrm{SPEC}$, Inc.

Attn: J.L. Ratigan

PO Box 725

Rapid City, SD 57709

Reynolds Electric and Engineering

Company, Inc.

Attn: E.W. Kendall

Building 790

Warehouse Row

PO Box 98521

Las Vegas, NV 89193-8521
SAIC

Attn: H.R. Pratt

10260 Campus Point Drive

San Diego, CA 92121

SAIC

Attn: C.G. Pflum

101 Convention Center Dr.

Las Vegas, NV 89109

SAIC (3)

Attn: M. Davis

R. Guzowski

J. Tollis on

2109 Air Park Road SE

Albuquerque, NM 87106

SAIC (2)

Attn: J. Young

D. Lester

18706 North Creek Parkway, Suite 110

Bothe11, WA 98011

Southwest Research Institute

Nuclear Waste Regulatory Analysis (2)

Attn: P.K. Nair

6220 Culebra Road

San Antonio, TX 78228-0510

Systems, Science, and Software (2)

Attn: E. Peterson

P. Lagus

Box 1620

La Jolla, CA 92038

TASC

Attn: S.G. Oston

55 Walkers Brook Drive

Reading, MA 01867

Tech Reps, Inc. (6)

Attn: J. Chapman

C. Crawford

D. Marchand

T. Peterson

J. Stikar

D. Scott

5000 Marble NE, Suite 222

Albuquerque, NM 87110

Tolan, Beeson \& Associates

Attn: T.L. Tolan

2320 W. 15th Avenue

Kennewick, WA 99337 
TRW Environmental Safety Systems (2)

Attn: I. Sacks, Suite 800

L. Wildman, Suite 1300

2650 Park Tower Drive

Vienna, VA 22180-7306

Sanford Cohen and Associates

Attn: J . Channe11

7101 Carriage Rd NE

Albuquerque, NM 87109

Westinghouse Electric Corporation (5)

Attn: Library

C. Cox

L. Fitch

B.A. Howard

R.F. Kehrman

PO Box 2078

Carlsbad, NM 88221

Westinghouse Hanford Company

Attn: D.E. Wood, MSIN HO-32

PO Box 1970

Richland, WA 99352

Western Water Consultants

Attn: P.A. Rechard

PO Box 4128

Laramie, WY 82071

Western Water Consultants

Attn: D. Fritz

1949 Sugarland Drive \#134

Sheridan, WY 82801-5720

P. Drez

8816 Cherry Hills Road NE

Albuquerque, NM 87111

David Leche1

9600 Allende Rd. NE

Albuquerque, NM 87109

C.A. Marchese

PO Box 21790

Albuquerque, NM 87154

Arend Meijer

3821 Anderson SE

Albuquerque, NM 87108

\author{
D.W. Powers \\ Star Route Box 87 \\ Anthony, TX 79821 \\ Shirley Thieda \\ PO Box 2109, RR1 \\ Bernalillo, NM 87004 \\ Jack Urich \\ c/o CARD \\ 144 Harvard SE \\ Albuquerque, NM 87106
}

\section{Universities}

University of California

Mechanical, Aerospace, and

Nuclear Engineering Department (2)

Attn: W. Kastenberg

D. Browne

5532 Boelter Hall

Los Angeles, CA 90024

University of California

Engineering and Applied Science

Attn: D. Okrent

48-121A Engineering IV

Los Angeles, CA 90024-1597

University of California

Mine Engineering Department

Rock Mechanics Engineering

Attn: N. Cook

Berkeley, CA 94720

University of Hawail at Hilo

Business Administration

Attn: S. Hora

Hilo, HI 96720-4091

University of Illinois

Department of Geology

Attn: C. Bethke

$1301 \mathrm{~W}$. Green St.

Urbana, IL 61801

University of New Mexico

Geology Department

Attn: Library

Albuquerque, NM 87131 
University of New Mexico

Research Administration

Attn: H. Schreyer

102 Scholes Hall

Albuquerque, NM 87131

University of Wyoming

Department of Civil Engineering

Attn: V.R. Hasfurther

Laramie, WY 82071

University of Wyoming

Department of Geology

Attn: J.I. Drever

Laramie, WY 82071

University of Wyoming

Department of Mathematics

Atin: R.E. Ewing

Laramie, WY 82071

\section{Libraries}

Thomas Brannigan Library

Attn: D. Dresp

106 W. Hadley St.

Las Cruces, NM 88001

New Mexico State Library

Attri: N. MuCallan

325 Don Gaspar

Santa Fe, NM 87503

New Mexico Tech

Martin Speere Memorial Library

Campus Street

Socort-, NM 87810

New Mexico Junior College

Pannell Library

Attn: R. Hill

Lovington Highway

Hobbs, NM 88240

Carlsbad Municipal Library

WIPP Public Reading Room

Attn: L. Hubbard

$101 \mathrm{~S}$. Halagueno St.

Carlsbad, NM 88220
University of New Mexico

Zimmerman Library

Government Publications Department

Albuquerque, NM 87131

\section{NEA/Performance Assessment Advisory Group (PAAG)}

P. Duerden

ANSTO

Lucas Heights Research Laboratories

Private Mail Bag No. 1

Menai, NSW 2234

AUSTRALIA

Gordon S. Linsley

Division of Nuclear Fuel Cycle and Waste Management

International Atomic Energy Agency

PO Box 100

A-1400 Vienna, AUSTRIA

Nicolo Cadelli

Commission of European Communities 200, Rue de la Loi

B-1049 Brissels, BELGIUM

R. Heremans

Organisme Nationale des Déchets

Radioactifs et des Matiéres Fissiles (ONDRAF)

Place Madou 1, Boitec 24/25

B-1030 Brussels, BELGIUM

J. Marivoet

Centre d'Etudes de 1'Energie

Nucléaire (CEN/SCK)

Boeretang 200

B-2400 Mo1, BELGIUM

P. Conlon

Waste Management Division

Atomic Energy Control Board (AECB)

PO Box 1046

Ottawa, Ontario KIP 559, CANADA

A.G. Wikjord

Manager, Environmental and Safety

Assessment Branch

Atomic Energy of Canada Limited

Whiteshell Research Establishment

Pinawa, Manitoba ROE 1LO, CANADA 
Teollisuuden Voima Oy (TVO) (2)

Attn: Timo Äikăs Jukka-Pekka Salo

Annankatu $42 \mathrm{C}$

SF-00100 Helsinki Suomi, FINLAND

Timo Vieno

Technical Research Centre of Finland (VTT)

Nuclear Energy Laboratory

PO Box 208

SF-02151 Espoo, FINLAND

Division de la Sécurité et de la Protection de 1'Environment (DSPE)

Commissariat á l'Energie Atomique Agence Nationale pour la Gestion des Déchets Radioactifs (ANDRA)

Attn: Gérald Ouzounian

M. Claude Ringeard

Route du Panorama Robert Schuman

B. P. No. 38

F-92266 Fontenay-aux-Roses Cedex

FRANCE

Claudio Pescatore

Division of Radiation Protection and

Waste Management

OECD Nuclear Energy Agency

38, Boulevard Suchet

F-75016 Paris

FRANCE

M. Dominique Greneche

Commissariat á l'Energie Atomique IPSN/DAS/SASICC/SAED

B.P. No. 6

F-92265 Fontenay-aux-Roses Cedex

FRANCE

Robert Fabriol

Bureau de Recherches Géologiques et Miniéres (BRGM)

B.P. 6009

45060 Orléans Cedex 2

FRANCE

P. Bogorinski

Gesellschaft für Reaktorsicherheit

(GRS) MBH

Schwertnergasse 1

D-5000 Köln 1, GERMANY
R. Storck

GSF - Institut füx Tieflagerung

Theodor-Heuss-Strabe 4

D-3300 Braunschweig, GERMANY

Ferrucio Gera

ISMES S.P.A

Via del Crociferi 44

I-00187 Rome, ITALY

Hiroyuki Umeki

Isolation System Research Program Radioactive Waste Management Project Power Reactor and Nuclear Fuel

Development Corporation (PNC)

1-9-13, Akasaka, Minato-ku

Tokyo 107

JAPAN

Tönis Papp

Swedish Nuclear Fuel and Waste

Management Co.

Box 5864

S 10248 Stockholm

SWEDEN

Conny Hägg

Swedish Radiation Protection

Institute (SSI)

Box 60204

S-104 01 Stockholm, SWEDEN

$\mathrm{J}$. Hadermann

Paul Scherrer Institute

Waste Management Programme

CH-5232 Villigen PSI

SWITZERLAND

J. Vigfusson

HSK-Swiss Nuclear Safety Inspectorate

Federal Office of Energy

$\mathrm{CH}-5232$ Villigen-HSK

SWITZERLAND

D.E. Billington

Departmental Manager-Assessment

Studies

Radwaste Disposal R\&D Division

AEA Decommissioning \& Radwaste

Harwell Laboratory, B60

Didcot Oxfordshire OX11 ORA

UNITED KINGDOM 
P. Grimwood

Waste Management Unit

BNFL

Sellafield

Seascale, Cumbria CA20 1PG

UNITED KINGDOM

Alan J. Hooper

UK Nirex Ltd

Curie Avenue

Harwe11, Didcot

Oxfordshire, OX11 ORH

UNITED KINGDOM

Jerry M. Boak

Yucca Mountain Project Office

US Department of Energy

PO Box 98608

Las Vegas, NV 89193

Seth M. Coplan (Chairman)

US Nuclear Regulatory Commission

Division of High-Level Waste

Management

Mail Stop 4-H-3

Washington, DC 20555

A.E. Van Luik

INTERA/M\&O

The Valley Bank Center

101 Convention Center Dr.

Las Vegas, NV 89109

\section{NEA/Probabilistic System Assessment Group (PSAG)}

Shaheed Hossain

Division of Nuclear Fuel Cycle and Waste Management

International Atomic Energy Agency Wagramerstrasse 5

PO Box 100

A-1400 Vienna, AUSTRIA

Alexander Nies (PSAC Chairman)

Gesellschaft für Strahlen- und

Institut für Tieflagerung

Abteilung für Endlagersicherheit

Theodor-Heuss-Strasse 4

D-3300 Braunschweig

GERMANY
Eduard Hofer

Gesellschaft für Reaktorsicherheit

(GRS) MBH

Forschungs gelände

D-8046 Garching, GERMANY

Andrea Saltelli

Commission of the European

Communities

Joint Resarch Centre of Ispra

I-21020 Ispra (Varese)

ITALY

Alejandro Alonso

Cátedra de Tecnología Nuclear

E.T.S. de Ingenieros Industriales

José Gutiérrez Abascal, 2

E-28006 Madrid, SPAIN

ENRESA (2)

Attn: M. A. Cuñado

F. J. Elorza

Calle Emilio Vargas, 7

E-28043 Madrid, SPAIN

Pedro Prado

CIEMAT

Instituto de Tecnología Nuclear

Avenida Complutense, 22

E-28040 Madrid, SPAIN

Nils A. Kjellbert

Swedish Nuclear Fuel and Waste

Management Company (SKB)

Box 5864

S-102 48 Stockholm, SWEDEN

Björn Cronhjort

Royal Institute of Technology

Automatic Control

S-100 44 Stockholm, SWEDEN

Richard A. Klos

Paul-Scherrer Institute (PSI)

$\mathrm{CH}-5232$ Villingen PSI, SWITZERLAND

Nationale Genossenschaft für die

Lagerung Radioaktiver Abfälle (2)

Attn: C. McCombie

F. Van Dorp

Hardstrasse 73

CH-5430 Wettingen, SWITZERLAND 
N. A. Chapman

Intera Information Technologies

Park View House

14B Burton Street

Melton Mowbray

Leicestershire LE13 1AE

UNITED KINGDOM

Daniel A. Galson

Galson Sciences Ltd.

35, Market Place

Oakham

Leicestershire LE15 6DT

UNITED KINGDOM

David P. Hodgkinson

Intera Information Technologies

45. Station Road, Chiltern House

Henley-on-Thames

Oxfordshire RG9 1AT

UNITED KINGDOM

Brian G.J. Thompson

Department of the Environment: Her

Majesty's Inspectorate of Pollution

Room A5.33, Romney House

43 Marsham Street

London SWIP 2PY, UNITED KINGDOM

Intera Information Technologies

Attn: M.J.Apted

3609 South Wadsworth Blvd.

Denver, CO 80235

US Nuclear Regulatory Commission (2)

Attn: R. Code11

N. Eisenberg

Mail Stop 4-H-3

Washington, DC 20555

Battelle Pacific Northwest

Laboratories

Attn: P.W. Eslinger

MS K2 - 32

PO Box 999

Richland, WA 99352

Center for Nuclear Waste Regulatory

Analys is (CNWRA)

Southwest Research Institute

Attn: B. Sagar

PO Drawer 28510

6220 Culebra Road

San Antonio, TX 78284

\section{Geostatistics Expert Working Group (GXG)}

Rafae1 L. Bras

R.L. Bras Consulting Engineers

44 Percy Road

Lexington, MA 02173

Jesus Carrera

Universidad Politécnica de Cataluña

E.T.S.I. Caminos

Jordi, Girona 31

E-08034 Barcelona, SPAIN

Gedeon Dagan

Department of Fluid Mechanics and

Heat Transfer

Tel Aviv University

PO Box 39040

Ramat Aviv, Tel Aviv 69978

ISRAEL

Ghislain de Marsily (GXG Chairman)

University Pierre et Marie Curie

Laboratorie de Geologie Applique

4, Place Jussieu

T. 26 - 5 e etage

75252 Paris Cedex 05

FRANCE

Alain Galli

Centre de Geostatistique

Ecole des Mines de Paris

35 Rue St. Honore

77035 Fontainebleau, FRANCE

Christian Ravenne

Geology and Geochemistry Division

Institut Francais du Pétrole

$1 \& 4$, Av. de Bois-Préau B.P. 311

92506 Rueil Malmaison Cedex

FRANCE

Peter Grindrod

INTERA Information Technologies Ltd.

Chiltern House

45 Station Road

Henley-on-Thames

Oxfordshire, RG9 1AT, UNITED KINGDOM 
Alan Gutjahr

Department of Mathematics

New Mexico Institute of Mining and

Technology

Socorro, NM 87801

C. Peter Jackson

Harwell Laboratory

Theoretical Studies Department

Radwaste Disposal Division

Bldg. 424.4

Oxfordshire Didcot Oxon OX11 ORA

UNITED KINDGOM

Rae Mackay

Department of Civil Engineering

University of Newcastle Upon Tyne

Newcastle Upon Tyne NE1 7RU

UNITED KINGDOM

Steve Gorelick.

Department of Applied Earth Sciences

Stanford University

Stanford, CA 94305-2225

Peter Kitanidis

60 Peter Coutts Circle

Stanford, CA 94305

Dennis McLaughlin

Parsons Laboratory

Room 48-209

Department of Civil Engineering

Massachusetts Institute of Technology

Cambridge, MA 02139

Shlomo P. Neuman

College of Engineering and Mines

Hydrology and Water Resources Dept.

University of Arizona

Tucson, AZ 85721

Yoram Rubin

Department of Civil Engineering

University of California

Berkeley, CA 94720

\section{Foreign Addresses}

Studiecentrum Voor Kernenergie

Centre D'Energie Nucleaire

Attn: A. Bonne

SCK/CEN

Boeretang 200

B-2400 Mol, BELGIUM

Atomic Energy of Canada, Ltd. (3)

Whiteshell Research Establishment

Attn: M.E. Stevens

B.W. Goodwin

D. Wushke

Pinewa, Manitoba ROE 1L0, CANADA

Juhani Vira

Teollisuuden Voima Oy (TVO)

Annankatu $42 \mathrm{C}$

SF-00100 Helsinki Suomi

FINLAND

Jean-Pierre 01ivier

OECD Nuclear Energy Agency (2)

38, Boulevard Suchet

F-75016 Paris, FRANCE

D. Alexandre, Deputy Director

ANDRA

31 Rue de la Federation

75015 Paris, FRANCE

Claude Sombret

Centre D'Etudes Nucleaires

De La Vallee Rhone

CEN/VALRHO

S.D.H.A. B.P. 171

30205 Bagnols-Sur-Ceze, FRANCE

Commissariat a L'Energie Atomique

Attn: D. Alexandre

Centre d'Études de Cadarache

13108 Saint Paul Lez Durance Cedex FRANCE

Bundesministerium für Forschung und Technologie

Postfach 200706

5300 Bonn 2, GERMANY 
Bundesanstalt für Geowissenschaften und Rohstoffe

Attn: M. Langer

Postfach 510153

D-30631 Hannover, GERMANY

Gesellschaft für Anlagen und

Reaktorsicherheit (GRS)

(2)

Attn: B. Baltes

W. Muller

Schwertnergasse 1

D-50667 Cologne, GERMANY

Institut fur Tieflagerung (2)

Attn: K. Kuhn

Theodor-Heuss-Strasse 4

D-3300 Braunschweig

GERMANY

Physikalisch-Technische Bundesanstalt

Attn: P. Brenneke

Postfach 3345

D-3300 Braunschweig

GERMANY

Shingo Tashiro

Japan Atomic Energy Research

Institute

Tokai-Mura, Ibaraki-Ken

319-11, JAPAN

Netherlands Energy Research

Foundation (ECN)

Attn: L.H. Vons

3 Westerduinweg

PO Box 1

1755 ZG Petten

THE NETHERLANDS

Johan Andersson

Swedish Nuclear Power Inspectorate

Statens Kärnkraftinspektion (SKI)

Box 27106

S-102 52 Stockholm

SWEDEN

Fred Karlsson

Svensk Kärnbrănsleforsorjning $A B$

Project KBS

Box 5864

S-102 48 Stockholm

SWEDEN
Nationale Genossenschaft für die

Lagerung Radioaktiver Abfalle (2)

Attn: S. Vomvoris

P. Zuidema

Hardstrasse 73

$\mathrm{CH}-5430$ Wettingen

SWITZERLAND

AEA Technology

Attn: J.E. Tinson

B4244 Harwe11 Laboratory

Didcot, Oxfordshire OX11 ORA

UNITED KINGDOM

AEA Technology

Attn: J.H. Rees

D5W/29 Culham Laboratory

Abington

Oxfordshire OX14 3DB

UNITED KINGDOM

AEA Technology

Attn: W.R. Rodwell

044/A31 Winfrith Technical Centre

Dorchester

Dorset DT2 8DH, UNITED KINGDOM

D.R. Knowles

British Nuclear Fuels, plc

Risley, Warrington

Cheshire WA3 6AS, 1002607

UNITED KINGDOM

\begin{tabular}{|c|c|c|}
\hline & & Internal \\
\hline MS & Org. & \\
\hline$\overline{0101}$ & $\overrightarrow{0001}$ & A. Narath \\
\hline 0102 & 0002 & O.E. Jones \\
\hline 0827 & 1502 & P.J. Hommert \\
\hline 327 & 1511 & D.K. Gartling \\
\hline 127 & 4511 & D.P. Garber \\
\hline 724 & 6000 & D.L. Hartley \\
\hline 324 & 6115 & P.B. Davies \\
\hline 324 & 6115 & R.L. Beauheim \\
\hline 0750 & 6118 & H.R. Westrich \\
\hline 1320 & 6119 & E.J. Nowak \\
\hline 1320 & 6119 & Staff (14) \\
\hline 1322 & 6121 & J.R. Tillerson \\
\hline 1322 & 6121 & Staff $(7)$ \\
\hline 1337 & 6300 & D.E. E11is \\
\hline 1335 & 6302 & L.E. Shephard \\
\hline 1335 & 6303 & S.Y. Pickering \\
\hline 1335 & 6303 & W.D. Weart \\
\hline 1335 & 6305 & S.A. Goldstein \\
\hline
\end{tabular}




\begin{tabular}{lll}
1335 & 6305 & A.R. Lappin \\
1341 & 6306 & A.L. Stevens \\
1326 & 6312 & F.W. Bingham \\
1326 & 6313 & L.S. Costin \\
1345 & 6331 & P.A. Davis \\
1330 & 6352 & WIPP Central F1les (100) \\
1328 & 6342 & D.R. Anderson \\
1328 & 6342 & P. Swift (20) \\
1328 & 6342 & B. Baker \\
1328 & 6342 & J. Garner \\
1328 & 6342 & J. He1ton \\
1328 & 6342 & D. Rudeen \\
1328 & 6342 & Staff (30) \\
1328 & 6343 & V. Harper-Slaboszewicz \\
1328 & 6343 & Staff (3) \\
1341 & 6345 & R.C. Lincoln \\
1341 & 6345 & Staff (9) \\
1341 & 6347 & D.R. Schafer \\
1341 & 6348 & J.T. Holmes \\
1341 & 6348 & Staff (4) \\
1343 & 6351 & R.E. Thompson \\
1330 & 6352 & S.E. Sharpton \\
0736 & 6400 & N.R. Ortiz \\
0746 & 6613 & R.M. Cranwel1 \\
0746 & 6613 & R.L. Iman \\
0746 & 6613 & C. Leigh \\
0727 & 6622 & M.S.Y. Chu \\
0718 & 6641 & R.E. Luna, Acting \\
0899 & 7141 & Technical Library (5) \\
0619 & 7151 & Technical Publications \\
0100 & $7613-2$ Document Processing for \\
& \multicolumn{2}{|l}{ DOE/OSTI (10) } \\
9018 & $8523-2$ Central Technical Files
\end{tabular}



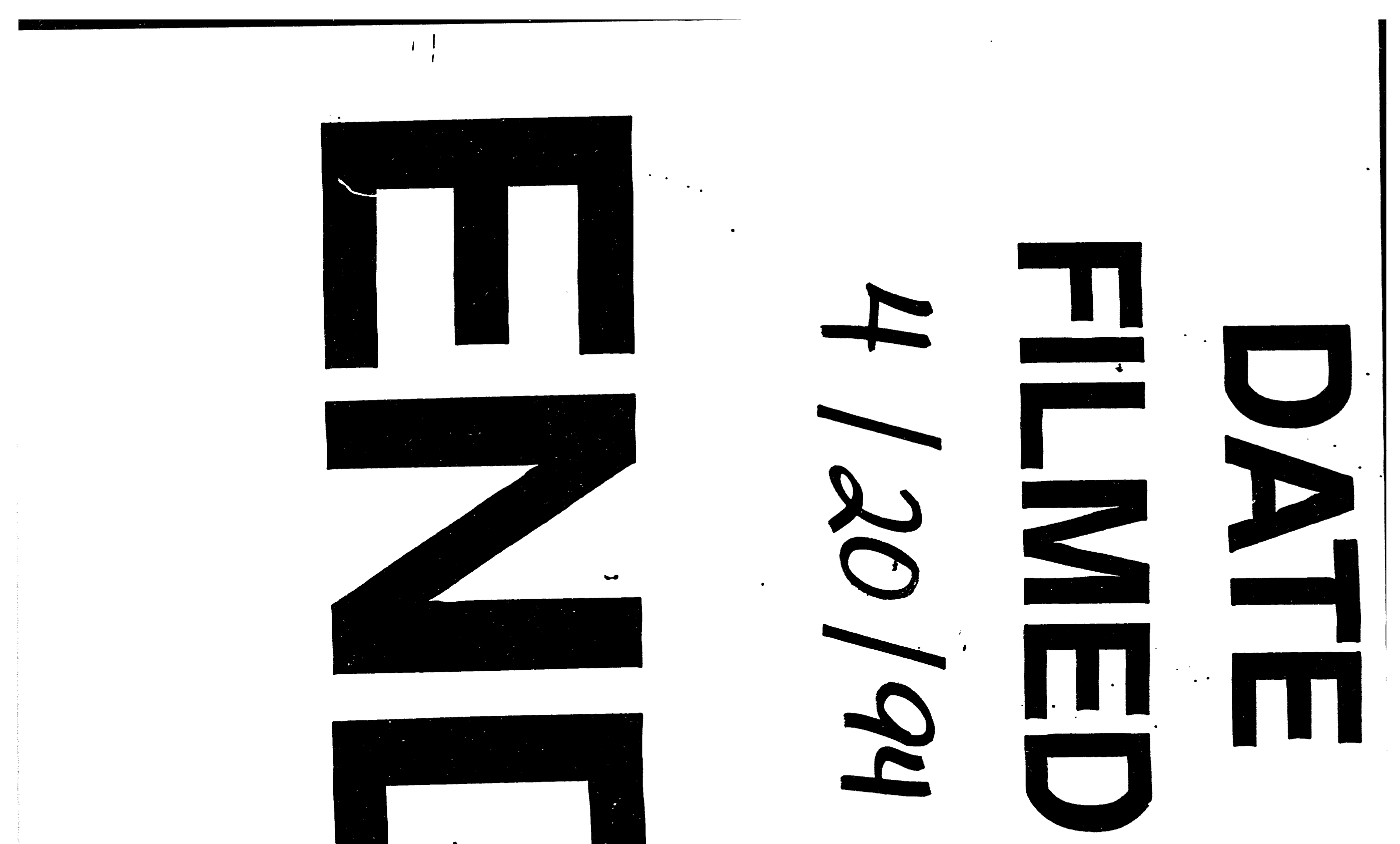
